\title{
MODEL OF A FUZZY DYNAMIC DECISION SUPPORT SYSTEM
}

DOI: $10.36724 / 2072-8735-2020-14-9-43-47$

Sergey V. Pavlov,

MTUCl, Moscow, Russia, h.I08@yandex.ru

Vladimir A. Dokuchaev,

MTUCl, Moscow, Russia, v.a.dokuchaev@mtuci.ru

Sergey S. Mytenkov,

HSE, Moscow, Russia, mitenkovss@rspp.ru
Manuscript received 03 July 2020;

Accepted 07 September 2020

Keywords: decision support system decision maker, deterministic, non-deterministic (fuzzy), fuzzy

multicriteria ranking, technical system

Within the framework of this article, the analysis of the ways of building an automated decision support system for business and technological processes based on the thematic apparatus of the theory of fuzzy functions is carried out. The purpose of decision support systems is to help the decision maker (business owners, top managers of companies, heads of state organizations and law enforcement agencies) in choosing the most optimal solution based on the information at his disposal. It is proposed to use mathematical methods based onfuzzy multicriteria ranking as methods for making a decision. The paper proposes a model of an automated decision support system for business and technological processes of organizations based onthe mathematical apparatus of the theory of fuzzy functions, which allows automating the process of choosing a solution and eliminating the influence of subjective factors when assessing possible decisions.

Information about authors:

Sergey V. Pavlov, PhD (Tech), Associate Professor of the Department "Network Information Technologies and Services" MTUCl, Moscow, Russia Vladimir A. Dokuchaev, ORCID: 0000-0002-4638-9352, DSC (Tech), Professor, Head of the Department "Network Information Technologies and Services" MTUCI, Moscow, Russia

Sergey S. Mytenkov, Lecturer at the Department of Theory and Practice of Business Interaction,HSE, Moscow, Russia

Для цитирования:

Павлов С.В., Докучаев В.А., Мытенков С.С. Модель нечеткой динамической системы поддержки принятия решений // Т-Сотт: Телекоммуникации и транспорт. 2020. Том 14. №9. С. 43-47.

For citation:

Pavlov S.V., Dokuchaev V.A., Mytenkov S.S. (2020) Model of a fuzzy dynamic decision support system. T-Comm, vol. I4, no.9, Pp. 43-47. (in Russian) 
Decision support systems (DSS) are becoming more widespread as an integral part of an automated business and technological process management system. The creation of these systems is especially important in the face of growing volumes of analyzed data and increased risks of losing confidential information $[1,2]$. The main purpose of these systems is to help the Decision-Maker (DM) choose the optimal solution to the task assigned to him based onthe use of the forces and means at his disposal to solve a specific task. The efficiency of the automated decision support system in solving special problems largely depends of the conditions in which it is used.

The basis of the DSS is the choice of the most adequate strategy of personnel behavior in the existing conditions to the basis of a comparative assessment of various models of its behavior. The task of the DSS is to collect information and prepare substantiated baseline data for making an adequate management decision.

Modern mathematics for solving DSS problems offers decision-making methods based on fuzzy multicriteria ranking. The fundamentals of such methods are described in [3-5]. Consider the application of the method based on the definition of the membership function, since this method is equally applicable to the solution of deterministic and non-deterministic (fuzzy) problems.

Consider the mathematical formulation of the problem of fuzzy multicriteria ranking:

1. Let the set $S=\left\{S_{i}, i=1, \ldots, n\right\}$ be the set of systems that can be applied to solve the set control problem.

2. The choice of the syste $S_{i}$ is carried out on the basis of using the quality indicator of the system (vector criterion) $F\left(S_{i}\right)=\left\{f_{1}\left(S_{i}\right), f_{2}\left(S_{i}\right), \ldots, f_{k}\left(S_{i}\right)\right\}$, where $f_{k}\left(S_{i}\right)$ is the quotient system criterion $k$.

3. $A=\left\{a_{j}\right\}$, where $a_{j}$ is the coefficient representing the importance of taking into account the $j$-th criterion of the system in the general indicator of the system's compliance with the possibility of solving the control problem.

4. $D_{f_{k}\left(S_{i}\right)}$ is the membership function of the fuzzy relation of strict nondominance, which shows the degree of nondominance of the system $S_{i}$ to none of the other systems by the criterion under consideration:

$$
D_{f_{k}\left(S_{i}\right)}=\min D_{f_{k}\left(S_{i}\right), f_{k}\left(S_{j}\right)}^{n d} .
$$

5. $D_{f_{k}\left(S_{i}\right), f_{k}\left(S_{j}\right)}$ is the membership function of the fuzzy dominance relation, which shows the degree of dominance of the system $S_{i}$ by the system $S_{j}$ according to a certain criterion.

6. $D_{f_{k}\left(S_{i}\right), f_{k}\left(S_{j}\right)}^{n d}$ is the membership function of the fuzzy relation of non-dominance of the system $S_{i}$ by the system $S_{j}$ according to the criterion $k$ :

$$
D_{f_{k}\left(S_{i}\right), f_{k}\left(S_{j}\right)}^{n d}=1-D_{f_{k}\left(S_{i}\right), f_{k}\left(S_{j}\right)} .
$$

7. $D_{f_{k}\left(S_{i}\right)}^{n d}$ is the membership function of the fuzzy relation of the nondominance of the system $S_{i}$ to none of the other systems according to the $k-t h$ criterion

8. It is nece ary to find a set of ordered systems for which the following relation holds:

$$
D_{F\left(S_{i}\right)}^{o p t}=\max D_{F\left(S_{i}\right)}
$$

and build on its basis a Pareto tuple according to the degree of maximum dominance of systems.

To solve the ranking problem, we will apply a method based on the determination of private quality indicators $K_{k}$ for a pair of compared systems $S_{i}$ and $S_{j}$ according to a criterion determined by Zhukovin's formula [5]:

$$
D_{f_{k}\left(S_{i}\right), f_{k}\left(S_{j}\right)}=\left\{\begin{array}{c}
{\left[f_{k}\left(S_{i}\right)-f_{k}\left(S_{j}\right)\right] / M} \\
\text { if } f_{k}\left(S_{i}\right)-f_{k}\left(S_{j}\right)>0 \\
0, \text { if } f_{k}\left(S_{i}\right)-f_{k}\left(S_{j}\right)<0
\end{array}\right.
$$

where $M$ is the width of the interval for evaluating the system by the $j$-th criterion.

Taking into account the known possibility of transforming minimized criteria into maximized ones, for further calculations we will use only the case of $k$-th criteria being maximized. Then the $K_{k}$ indicator expresses the ratio of the dominance of the system $\left(S_{i}\right)$ by the rest of the systems according to the criterion. The degree of non-dominance $K_{k}^{*}$ of the system $\left(S_{i}\right)$ in this case can be easily expressed using the formula $K_{k}^{*}=1-K_{k}$.

In the course of research, the results of pairwise comparison of systems $S_{i}$ and $S_{j}$ are presented in the form of an evaluation matrix $\left\|C_{i j}\right\|$. Since the comparison takes place in pairs, in the future, to obtain a ranked list, it is necessary to use iterative or multi-step methods.

Based on the data of the matrix $\left\|C_{i j}\right\|$, the system $\mathrm{Si}$ is determined from the set of systems $S=\left\{S_{i}, i=1, \ldots, n\right\}$, for which the value of the non-dominance coefficient $K_{k}^{*}$ takes the minimum value. In accordance with the definition of non-dominance, such a system is not subject to dominance by any of the available set of systems $S_{i}$, and therefore is the best. In the presence of several systems with the same minimum $K_{k}^{*}$ indicators, the system with the minimum total value of private quality indicators is taken as the best. Systems with the same and this indicator are considered equivalent and are subject to ranking at the same position. After determining the most suitable system for compiling the ranking list, it is necessary to exclude from further consideration the corresponding $i$-th row and $j$-th column of the matrix $\left\|C_{i j}\right\|$ and repeat the search for the best system in the new set $S=\left\{S_{i}, i=1, \ldots, n-1\right\}$. 
For example, let for a comparative assessment of systems $S_{1}, S_{2}, S_{3}$ according to the criteria $f_{1}\left(S_{i}\right)$ and $f_{2}\left(S_{i}\right)$ there are the values of the criteria for each system presented in Table 1.

Table 1

\begin{tabular}{|c|c|c|c|}
\hline & $S_{1}$ & $S_{2}$ & $S_{3}$ \\
\hline$f_{1}\left(S_{i}\right)$ & 3.000 & 6.000 & 4.000 \\
\hline$f_{2}\left(S_{i}\right)$ & 10.000 & 8.000 & 2.000 \\
\hline
\end{tabular}

Then, using formula (1), the values of the non-dominance membership function $D_{f_{k}\left(S_{i}\right), f_{k}\left(S_{j}\right)}^{n d}$ for systems $S_{1}, S_{2}, S_{3}$ can be calculated according to the criteria $f_{1}\left(S_{i}\right)$ and $f_{2}\left(S_{i}\right)$. The calculation results are presented in Table 2.

Table 2

\begin{tabular}{|c|c|c|c|c|c|c|}
\hline & \multicolumn{3}{|c|}{$\begin{array}{c}\text { Функция } D_{f_{1}\left(S_{i}\right), f_{1}\left(S_{j}\right)}^{n d} \\
\text { Критерий } f_{1}\left(S_{i}\right)\end{array}$} & \multicolumn{3}{|c|}{$\begin{array}{c}\text { Функция } D_{f_{2}\left(S_{i}\right), f_{2}\left(S_{j}\right)}^{n d} \\
\text { Критерий } f_{2}\left(S_{i}\right)\end{array}$} \\
\hline & $S_{1}$ & $S_{2}$ & $S_{3}$ & $S_{1}$ & $S_{2}$ & $S_{3}$ \\
\hline$S_{1}$ & 1.000 & 1.000 & 1.000 & 1.000 & 0.800 & 0.200 \\
\hline$S_{2}$ & 0.500 & 1.000 & 0.667 & 1.000 & 1.000 & 0.400 \\
\hline$S_{3}$ & 0.833 & 1.000 & 1.000 & 1.000 & 1.000 & 1.000 \\
\hline
\end{tabular}

Then, based on the data in Table 2, in accordance with the formula in item 4 of the problem statement, the function $D_{f_{k}\left(S_{i}\right)}$ of the membership of the fuzzy relation of strict nondominance according to the criteria $f_{1}\left(S_{i}\right)$ and $f_{2}\left(S_{i}\right)$ is determined. Thus, the data in Table 2 will be converted to the form presented in Table 3.

Table 3

\begin{tabular}{|c|c|c|c|}
\hline & $S_{1}$ & $S_{2}$ & $S_{3}$ \\
\hline$f_{1}\left(S_{i}\right)$ & 0.500 & 1.000 & 0.667 \\
\hline$f_{2}\left(S_{i}\right)$ & 1.000 & 0.800 & 0.200 \\
\hline
\end{tabular}

Obviously, the comparison of three systems presented above for clarification by two criteria is a fairly trivial ranking problem that, with a certain skill, can be solved at an intuitive level. In particular, from the data in Table 3, it can be seen that the system $S_{2}$ is the most suitable for solving the problem, as it has the maximum coefficients in the table. However, even with an insignificant increase in the number of systems and / or criteria, the ranking problem immediately becomes much more complicated and the intuitively obtained solution becomes poorly justified.

The validity of the need to apply the theory of fuzzy functions will be shown by the example of determining the preference rank for the set of systems $S=\left\{S_{i}, i=1, \ldots, 6\right\}$. For each of the systems, Table 4 presents the values of $f_{k}\left(S_{i}\right)$ scalar criteria predetermined by expert estimates.
In addition, the same table shows the values of the weight coefficients $a_{j}$ for scalar criteria $\left\{f_{1}\left(S_{i}\right), \ldots, f_{4}\left(S_{i}\right)\right\}$.

Table 4

\begin{tabular}{|c|c|c|c|c|c|c|c|}
\hline & $S_{1}$ & $S_{2}$ & $S_{3}$ & $S_{4}$ & $S_{5}$ & $S_{6}$ & $a_{j}$ \\
\hline$f_{1}\left(S_{i}\right)$ & 4 & 2 & 3 & 5 & 8 & 9 & 0.15 \\
\hline$f_{2}\left(S_{i}\right)$ & 3 & 6 & 7 & 4 & 2 & 3 & 0.50 \\
\hline$f_{3}\left(S_{i}\right)$ & 8 & 4 & 9 & 3 & 2 & 5 & 0.30 \\
\hline$f_{4}\left(S_{i}\right)$ & 4 & 3 & 9 & 8 & 5 & 8 & 0.05 \\
\hline
\end{tabular}

Based on the data of a comparative assessment of systems by particular criteria, an evaluation matrix $\left\|C_{i j}\right\|$ was built according to the following rules:

1. he values of the elements $c_{i j}$ of the matrix for systems $S_{i}$ and $S_{j}$ with equivalent coefficients $j$ are taken equal to 1 .

2 . In the cas when all the values of the membership function $D_{f_{k}\left(S_{i}\right)}$ of the $j$-dominated system are greater than those of the $i$-th system, the values of $P_{1}$ are assigned to the elements of $c_{i j}$, much greater than $1\left(c_{i j}=P_{1} \gg 1\right)$.

3 . In the case when the $m$ values of the membership function $D_{f_{k}\left(S_{i}\right)}$ of the $j$-dominated system are greater than those of the $i$-th system, and their other elements have the same value, the value of $P_{2}$ is assigned to the elements $c_{i j}$, much greater than 1 , but less than

$$
P_{1}\left(c_{i j}=P_{2}=P_{1}^{*} m / n \gg 1, P_{1}>P_{2}\right)
$$

4. In the $\mathrm{c}$ e when the membership functions $D_{f_{k}\left(S_{i}\right)}$, $D_{f_{k}\left(S_{j}\right)}$ of both systems have both equal and larger and smaller values, the elements $c_{i j}$ are assigned values normalized to the maximum.

5. The values obtained during the calculation must be multiplied by the value of the corresponding weighting factor.

The resulting evaluation matrix is shown in Table 5.

Table 5

\begin{tabular}{|c|c|c|c|c|}
\hline & $f_{1}\left(S_{i}\right)$ & $f_{2}\left(S_{i}\right)$ & $f_{3}\left(S_{i}\right)$ & $f_{4}\left(S_{i}\right)$ \\
\hline$S_{i}$ & 0,067 & 0,214 & 0,267 & 0,022 \\
\hline$S_{2}$ & 0,033 & 0,429 & 0,133 & 0,017 \\
\hline$S_{3}$ & 0,050 & 0,500 & 0,300 & 0,050 \\
\hline$S_{4}$ & 0,083 & 0,286 & 0,267 & 0,044 \\
\hline$S_{5}$ & 0,133 & 0,143 & 0,167 & 0,026 \\
\hline$S_{6}$ & 0,150 & 0,214 & 0,267 & 0,044 \\
\hline
\end{tabular}


After determining the elements of the $c_{i j}$ matrix, the systems are ranked according to the degree of suitability for the task. For this, the rigid ranking method described in $[6,7]$ is used.

Calculations using the described method by the iterative method allowed us to obtain the estimated coefficients bi, which are a measure of the quality of the $i$-th sample of the Technical System, expressed in relative units. The index $i$ of the coefficient bi in this case denotes the serial number of the iteration. The values of the parameter bi calculated on the basis of the data in Table 5 are presented in Table 6 .

Table 6

\begin{tabular}{|c|c|c|c|c|c|}
\hline & $b_{0}$ & $b_{1}$ & $b_{2}$ & $b_{3}$ & $b_{4}$ \\
\hline$S_{i}$ & 1,000 & 0,445 & 0,416 & 0,410 & 0,408 \\
\hline$S_{2}$ & 1,000 & 0,545 & 0,530 & 0,527 & 0,526 \\
\hline$S_{3}$ & 1,000 & $\mathbf{0 , 7 5 5}$ & $\mathbf{0 , 7 2 4}$ & $\mathbf{0 , 7 1 8}$ & $\mathbf{0 , 7 1 6}$ \\
\hline$S_{4}$ & 1,000 & 0,524 & 0,493 & 0,487 & 0,485 \\
\hline$S_{5}$ & 1,000 & 0,315 & 0,289 & 0,284 & 0,283 \\
\hline$S_{6}$ & 1,000 & 0,472 & 0,435 & 0,428 & 0,426 \\
\hline
\end{tabular}

As can be seen from the data in Table 6, with an increase in the ordinal degree of iteration, the values of the coefficients bi tend to asymptotically approximate a certain value determined for each system $S_{i}$. Thus, it is advisable to carry out the iterative process before the step when the values of the indicator bi stop changing significantly at the next step of the iteration, i.e. while $b_{i+1} \approx b_{i}$. The obtained value $b_{i}$ is the desired indicator of the quality of the system. The choice of the vehicle is carried out according to the maximum value of the indicator bi at the stage of stopping the calculation process.

The values of the indicators $b_{i}$ (Table 6) at the 4th stage of iterations practically coincide with the corresponding indicators at the 3rd stage of iterations, which indicates the achievement of the specified accuracy in obtaining data for the comparative assessment of systems. The maximum value of the coefficient bi is located in the third line of the table and is highlighted in bold for clarity.

The preference rank of the set $S$ is constructed in decreasing order of the values of the coefficients $b_{i}$, which leads to the se- ries: $S=\left\{S_{3}, S_{2}, S_{4}, S_{6}, S_{1}, S_{5}\right\}$. Thus, according to the results of ranking calculations, it is advisable to choose the most appropriate in quality for solving the problem system $S_{3}$.

\section{Conclusion}

Models of behavior strategies when solving problems of operations control, in view of the difficulties of formalizing situations when solving special problems, are usually built on the basis of using the method of expert systems. This method is based on the principle of obtaining an objective (to some extent) assessment of an object, process or phenomenon on the basis of taking into account the private opinion of a number of experts, eliminating their private preferences.

The model of an automated decision support system for special purposes proposed by the authors based on the mathematical apparatus of the theory of fuzzy functions allows automating the process of choosing a solution and eliminating the influence of subjective factors when assessing possible decisions.

\section{References}

1. Dokuchaev V.A., Gorban E.V., MaklachkovaV.V. (2019). The system of indicators for risk assessment in high-loaded infocommunication systems. 2019 Systems of Signals Generating and Processing in the Field of on Board Communications, SOSG 2019. P. 8706726.

2. Dokuchaev V. A., Makarova D., Maklachkova V.V., Volkova L.V. (2020). Analysis of Data Risk Management Methods for Personal Data Information Systems. 2020 Systems of Signals Generating and Processing in the Field of on Board Communications. 19-20 March 2020, DOI: 10.1109/IEEECONF48371.2020.9078538.

3. Vedernikov Yu.V., Safronov V.V. (2008). Method of multicriteria ranking of complex systems with various types of initial data uncertainty. Information and control systems. No. 3.

4. Vederniko Yu.V. (2008). Set-theoretical justification for the choice of complex systems with heterogeneous initial information. $\mathrm{SPb}$. Publishing house of the RF Ministry of Defense.

5. Zhuk in V.E. (1988). Fuzzy multicriteria decision making models. Academy of Sciences of the Georgian SSR, Institute of Cybernetics. Tbilisi: Metsniereba. 69, [2] p. ISBN 5-520-00006-9.

6. Pavlov S.V., Dokuchaev V. (2018). Methodological foundations for building a model of radio monitoring equipment. T-Comm, vol. 12 , no.7, pp. $48-51$.

7. Pavlov S ., Dokuchaev V.A., Maklachkova V.V., Mytenkov S.S. (2019). Features of supporting decision making in modern enterprise infocommunication systems. T-Comm, vol. 13, no.3, pp. 71-74. 


\title{
МОДЕЛЬ НЕЧЕТКОЙ ДИНАМИЧЕСКОЙ СИСТЕМЫ ПОДДЕРЖКИ ПРИНЯТИЯ РЕШЕНИЙ
}

\author{
ПавловСергей Владимирович, МТУСИ, Москва, Россия, h.I08@yandex.ru \\ Докучаев Владимир Анатольевич, МТУСИ, Москва, Россия, v.а.dokuchaev@mtuci.ru \\ Мытенков СергейСергеевич, НИУ ВШЭ, Москва, Россия, mitenkovss@rspp.ru
}

\section{Аннотация}

В рамках настоящей статьи произведен анализ путей построения автоматизированной системы поддержки принятия решений бизнес и технологических процессов на основе тематического аппарата теории нечетких функций. Назначением систем поддержки принятия решений является помощь лицу, принимающему решение (владельцы бизнеса, топ-менеджеры компаний, руководители государственных организаций и силовых структур) в выборе наиболее оптимального решения на основе имеющихся в его распоряжении информации. В качестве методов для принятия решения на предлагается использовать математические методы на основе нечеткого многокритериального ранжирования. В работе предлагается модель автоматизированной системы поддержки принятия решений бизнес и технологических процессов организаций на основе математического аппарата теории нечетких функций, которая позволяет автоматизировать процесс выбора решения и исключить влияние субъективных факторов при оценке возможных решений.

Ключевые слова: система поддержки принятия решений, лицопринимающее решения, детерминированный, недетерминированный (нечеткий), нечеткое многокритериальное ранжирование, техническая система.

\section{Литература}

I. Dokuchaev V.A., Gorban E.V., Maklachkova V.V. The system of indicators for risk assessment in high-loaded infocommunication systems. Всборнике: 2019 Systems of Signals Generating and Processing in the Field of on Board Communications, SOSG 2019. 2019. C. 8706726.

2. Dokuchaev V.A., Makarova D., Maklachkova V.V., Volkova L.V. Analysis of Data Risk Management Methods for Personal Data Information Systems. Всборнике: 2020 Systems of Signals Generating and Processing in the Field of on Board Communications. 19-20 March 2020, DOI: I0.1 I09/IEEECONF4837I.2020.9078538.

3. Ведерников Ю.В., Сафронов В.В. Метод многокритериального ранжирования сложных систем при различных видах неопределенности исходных данных // Информационно-управляющие системы. 2008. №3.

4. Ведерников Ю.В. Теоретико-множественное обоснование выбора сложных систем при разнородной исходной информации. СПб. Изд-во МО РФ, 2008.

5. Жуковин В.Е. Нечеткие многокритериальные модели принятия решений. АН ГССР, Ин-т кибернетики. Тбилиси: Мецниереба, 1988. 69, [2] с.; 22 см.; ISBN 5-520-00006-9.

6. Павлов С.В., Докучаев В.А. О разработке методологических основ построения модели технических средств радиомониторинга // Т-Comm: Телекоммуникации и транспорт. 2018. Том 12. №7. С. 48-5I.

7. Павлов С.В., Докучаев В.А., Маклачкова В.В., Мытенков С.С. Особенности поддержки принятия решений в современных корпоративных инфокоммуникационных системах // Т-Comm: Телекоммуникации и транспорт. 2019. Том I3. №3. С. 7 I-74.

\footnotetext{
Информация об авторах:
}

ПавловСергей Владимирович, к.т.н., с.н.с., доценткафедры СИТиСМТУСИ, Москва, Россия

Докучаев Владимир Анатольевич, д.т.н., профессор, зав. кафедрой СИТиС МТУСИ, Москва, Россия

Мытенков СергейСергеевич, преподаватель кафедры теории и практики взаимодействия бизнеса НИУ ВШЭ, Москва, Россия 